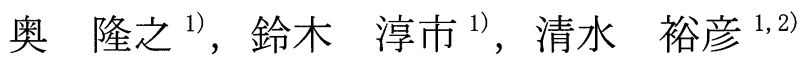 \\ $\left({ }^{1)}\right.$ 日本原子力研究所 先端基礎研究センター, ${ }^{2}$ 理化学研究所 イメージ情報研究ユニット)
}

\title{
Development of magnetic neutron lenses and their application to focusing geometry SANS
}

\author{
Takayuki Oku ${ }^{1)}$, Jun-ichi Suzuki ${ }^{1)}$, Hirohiko M. Shimizu ${ }^{1,2)}$ \\ ${ }^{1)}$ Advanced Science Research Center, JAERI, ${ }^{2)}$ Image Information Research Unit, RIKEN

\section{0}

\begin{abstract}
As a neutron has a magnetic dipole moment, we can control a neutron beam by using magnetic field gradient. A sextupole magnet functions as an ideal focusing lens for the neutron beam. By using the sextupole magnet, we can obtain precisely focused neutron beam free from neutron scattering and attenuation by substances. Thus, the sextupole magnet has been considered to be appropriate neutron focusing device for a focusing-geometry SANS (F-SANS) experiment. We have developed magnetic neutron lenses based on the sextupole magnet which has sufficiently large aperture and strong focusing power for the F-SANS experiment, and constructed a F-SANS instrument using the magnetic lens. Here, some results of the F-SANS experiments are also shown and discussed.
\end{abstract}

Keywords: magnetic neutron lens, sextupole magnet, cold neutron, beam focusing

\section{1.はじめに}

中性子散乱法は物性研究などにおいて基本的且 つ有用な研究手段である。しかし，実際に利用で きる中性子ビームの強度が X線などと比較して極 めて弱いことから，その適用範囲は強く制限され ている。この問題を解決するためには, 大強度中 性子源の開発に加えて, 発生した中性子を効率よ く輸送したり, 制御することが重要である。そこ で, 我々は, 中性子散乱研究における中性子ビー ムの利用効率の向上を目的として, 中性子磁気屈 折光学素子の開発とその応用に関する研究を行っ てきた. 中性子は電気的に中性であるが, 磁気モ 一メントを持っているため, 磁場勾配を用いて中 性子ビームを制御することが可能である。特に, 六極磁場は, 中性子に対して理想的なレンズとし て機能することが知られている[1]．以下，六極磁 石に基づく中性子集光素子を中性子磁気レンズと 称する. 中性子磁気レンズを用いて中性子を集光 する場合, 物質による中性子の吸収や散乱が全く ないことから, 非常に精度良く集光した中性子ビ 一ムを得ることができる. よって, 中性子磁気レ ンズは, 精度の高い集光ビームを必要とする集光 型小角散乱法へ適用が期待されている. しかし， その実現のためには $\phi 20 \mathrm{~mm}$ 程度以上の大きな口 径と実用レベルの中性子集光能力を持った中性子 磁気レンズを開発する必要があった.そこで, 我々 は，超伝導技術や特殊な磁気回路等を用いて，実 用レベルの中性子集光能力を持った中性子磁気レ
ンズの開発を行った。そして，その開発した中性 子磁気レンズを用いて集光型小角散乱装置の開発 研究を行った。 以下, 本稿では, 六極磁場を用い た中性子ビーム制御の原理から，磁気レンズを用 いた集光型小角散乱装置の開発まで，我々が取り 組んだ一連の開発研究の内容について紹介する.

\section{2. 六極磁場中での中性子の運動}

磁場中での中性子の運動は, 以下の 2 式で記述 される.

$$
\begin{aligned}
& \frac{\mathrm{d}^{2} \boldsymbol{r}}{\mathrm{d} t^{2}}=-\alpha \nabla(\sigma \cdot \boldsymbol{B}) \\
& \frac{\mathrm{d} \sigma}{\mathrm{d} t}=\gamma_{\mathrm{n}} \sigma \times \boldsymbol{B}
\end{aligned}
$$

ここで, $\boldsymbol{r}$ は中性子の座標， $\sigma$ は中性子スピンと平 行な単位べクトル, $\alpha=\left|\mu_{\mathrm{n}} / m_{\mathrm{n}}\right|=5.77 \mathrm{~m}^{2} \mathrm{~s}^{-2} \mathrm{~T}^{-1}$, $\gamma_{\mathrm{n}}\left(=2 \mu_{\mathrm{n}} / \hbar=-1.83 \times 10^{8} \mathrm{~s}^{-1} \mathrm{~T}^{-1}\right)$ は磁気回転比である. 式 (1), (2)より，中性子は磁場中でそのスピンと磁場 ベクトルの内積の勾配に沿って加速され，また， 中性子のスピンはラーモア周波数 $\omega_{\mathrm{L}}=-\gamma_{\mathrm{n}}|\boldsymbol{B}|$ で歳差 運動することが分かる．中性子が不均一磁場中を 飛行するとき, 中性子位置での磁場べクトルが変 化する. その磁場べクトルの回転角周波数を $\omega_{\mathrm{B}}=$ $\mid \partial \hat{\boldsymbol{B}} / \partial \boldsymbol{s} \mathrm{d} \boldsymbol{s} / \mathrm{d} t$ と定義する。 ここで $s$ は中性子の軌

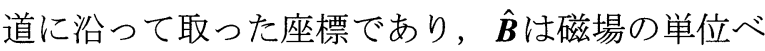
クトルである．磁場の強度が十分強く, $\omega_{\mathrm{L}} / \omega_{\mathrm{B}}>>1$ の関係が成立するとき，中性子のスピン状態はほ ぼ保存され，中性子は断熱的に輸送される。この 
場合, 磁場中での中性子の運動方程式は, 次式の ように簡単に記述できる。

$$
\frac{\mathrm{d}^{2} \boldsymbol{r}}{\mathrm{d} t^{2}}=\mp \alpha \nabla|\boldsymbol{B}|
$$

ここで，負号”-“は中性子スピンが正極性（中性 子スピンと磁場ベクトルが平行）の状態に，正 号”+“は負極性（中性子スピンと磁場ベクトルが 反平行）の状態にそれぞれ対応する。

六極磁場 $\boldsymbol{B}_{S}$ は, 次式で記述される.

$$
\boldsymbol{B}_{\mathrm{S}}=\frac{G}{2}\left(\begin{array}{c}
y^{2}-x^{2} \\
2 x y \\
0
\end{array}\right)
$$

ここで, $G$ は磁場強度勾配の大きさを表す磁場強 度勾配定数である。式(4)より，六極磁場強度の 分布は,

$$
\left|\boldsymbol{B}_{\mathrm{s}}\right|=\frac{G}{2}\left(x^{2}+y^{2}\right)
$$

と表される。式(5)を式(3)に代入すると，六極磁場 中での中性子の運動方程式 :

$$
\frac{\mathrm{d}^{2} x}{\mathrm{~d} t^{2}}=\mp \omega^{2} x, \quad \frac{\mathrm{d}^{2} y}{\mathrm{~d} t^{2}}=\mp \omega^{2} y, \quad \frac{\mathrm{d}^{2} z}{\mathrm{~d} t^{2}}=0
$$

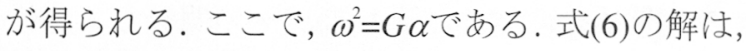
以下のように与えられる。

(i) 正極性の場合

$$
\begin{aligned}
& x(t)=x(0) \cos \left(\frac{\omega m_{\mathrm{n}} \lambda}{h} z(t)\right)+\frac{v_{\mathrm{x}}(0)}{\omega} \sin \left(\frac{\omega m_{\mathrm{n}} \lambda}{h} z(t)\right),(7) \\
& y(t)=y(0) \cos \left(\frac{\omega m_{\mathrm{n}} \lambda}{h} z(t)\right)+\frac{v_{\mathrm{y}}(0)}{\omega} \sin \left(\frac{\omega m_{\mathrm{n}} \lambda}{h} z(t)\right), \\
& z(t)=v_{\mathrm{z}}(0) t=\frac{h}{m_{\mathrm{n}} \lambda} t .
\end{aligned}
$$

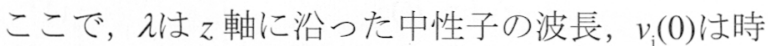
刻 $t=0$ における中性子の速度の $i(=x, y, z)$ 方向成分 である。もし，中性子が $z$ 軸と平行に六極磁場中 に入射した場合, 中性子は, $z=\pi h /\left(2 \omega m_{\mathrm{n}} \lambda\right)$ で焦点 を結ぶことになる（Fig. 1(a)）。

(ii) 負極性の場合

$$
\begin{aligned}
& x(t)=x(0) \cosh \left(\frac{\omega m_{\mathrm{n}} \lambda}{h} z(t)\right)+\frac{v_{\mathrm{x}}(0)}{\omega} \sinh \left(\frac{\omega m_{\mathrm{n}} \lambda}{h} z(t)\right), \\
& y(t)=y(0) \cosh \left(\frac{\omega m_{\mathrm{n}} \lambda}{h} z(t)\right)+\frac{v_{\mathrm{y}}(0)}{\omega} \sinh \left(\frac{\omega m_{\mathrm{n}} \lambda}{h} z(t)\right) \\
& z(t)=v_{\mathrm{z}}(0) t=\frac{h}{m_{\mathrm{n}} \lambda} t
\end{aligned}
$$

六極磁場内に入射した中性子ビームは, 磁場の 中心軸から遠ざかる方向に加速され，発散される (Fig. 1(b)).

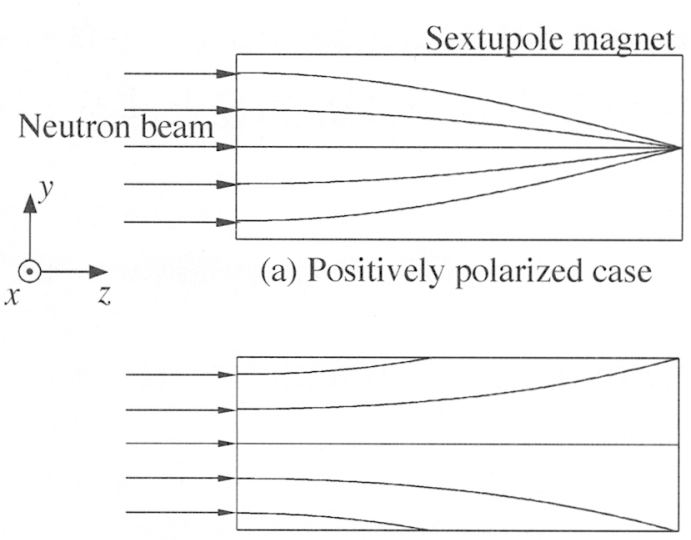

(b) Negatively polarized case

Fig. 1 Schematic illustration of the neutron trajectories when the neutrons are polarized (a) positively and (b) negatively against the local field in a sextupole magnet. Here, the incident neutron beams are parallel to the $z$-axis.

\section{3. 中性子磁気レンズの開発}

六極磁場の中性子集光効果は，これまでに 6 ピ 一ス型の永久六極磁石を用いた中性子ビーム実験 で検証されている[1].この検証実験で用いられた 磁気レンズは，口径が $\phi 10 \mathrm{~mm}$ であった（Fig. 2). この磁気レンズを集光型小角散乱法へ適用するた めには, 口径 $\phi 20 \mathrm{~mm}$ 程度以上で, 且つ, 波長 $6 \AA$ の中性子を焦点距離 $f \sim 10 \mathrm{~m}$ で集光する能力を持 った磁気レンズを開発する必要があった。ここで， 焦点距離 $f$ は, Fig. 3 に示した体系において，次式 で定義した。

$$
f=\frac{L_{\mathrm{mag}}}{2}+\frac{h}{\omega m_{\mathrm{n}} \lambda} \cot \left(\frac{\omega m_{\mathrm{n}} \lambda}{h} \cdot \frac{L_{\mathrm{mag}}}{2}\right)
$$

ただし， $L_{\mathrm{mag}}$ は磁気レンズの長さである。しかし， 6 ピース型の永久六極磁石を単純に大口径化する と, 磁場強度勾配定数 $G$ は, 磁気レンズ内径の自 乗にほぼ反比例して減少することから，十分な中 性子集光能力を持った磁気レンズを得ることはで

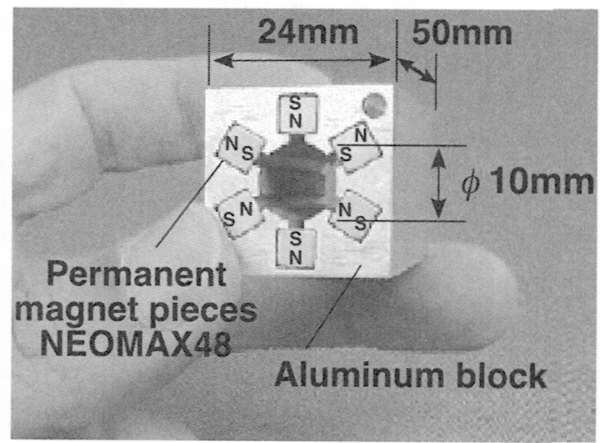

Fig. 2 Permanent sextupole magnet with 6 pieces of Nd-Fe-B magnets. 


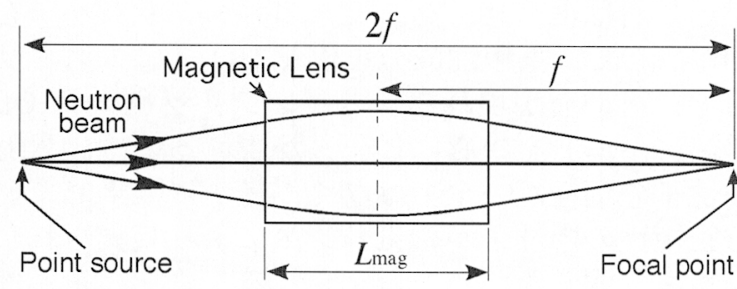

Fig. 3 A definition of focal length $f$.

きない，そこで，我々は，超伝導技術や特殊な磁 気回路を用いて，大口径で実用レベルの中性子集 光能力を持った中性子磁気レンズを開発した

（Table 1）[2,3]. 超伝導六極電磁石は，Nb-Ti 線で 巻かれた 6 個の鞍型コイル（Fig. 4）で六極磁場を 発生し, 約 $\phi 50 \mathrm{~mm}$ の大口径を有する。発展型 Halbach 六極永久磁石は, Fig. 5 に示した特殊な磁 気回路からなり，永久磁石でありながら，同じ内 径の 6 ピース型六極永久磁石と比較して, 3 倍強 の磁場強度を発生することができる。また，六極 磁場を用いて中性子を集光する場合，式(13)から 分かるように，中性子波長に依存して焦点距離が 変化するため色収差が生じるが，我々はパルス中 性子を一定の焦点距離で集光することを目的とし たパルス六極電磁石の開発にも現在取り組んでい る（Table 1）[4,5].これは，時間と共に変化する 入射中性子の波長に同期させて，パルス的に六極 磁場強度を変化させて, 一定の焦点距離でパルス 中性子ビームを集光するものである.

4. 磁気レンズを用いた集光型小角散乱装置の開発

小角散乱法とは，散乱角の小さな領域を測定す る散乱手法である。小さな散乱角を測定するため に, 通常の中性子小角散乱装置では, Fig. 6(a)のよ うに2つのピンホールスリットを用いて，入射中

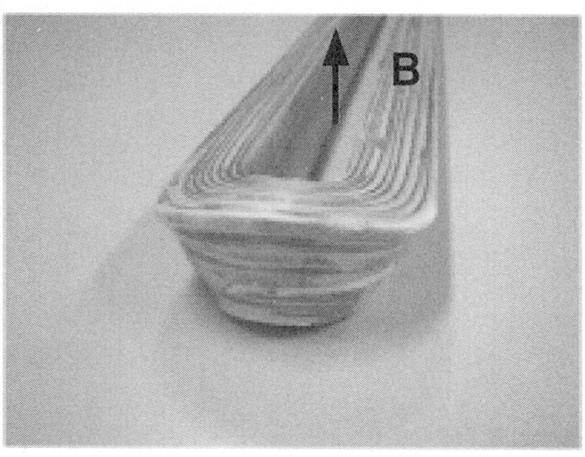

Fig. 4 Saddle-shaped Nb-Ti superconducting coil.

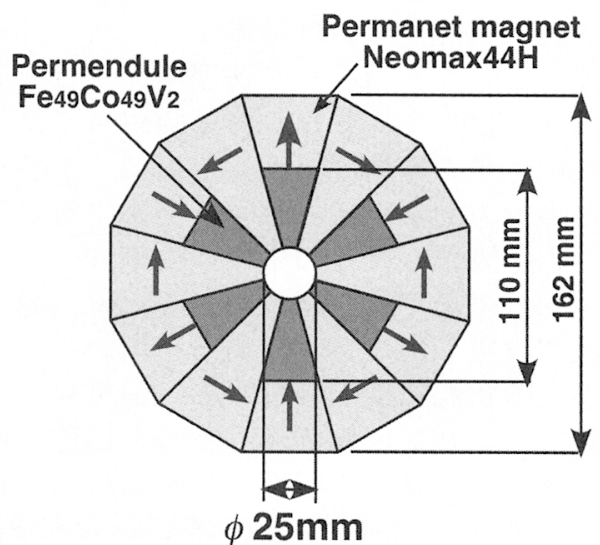

Fig. 5 Magnetic circuit of the Extended-Halbach type sextupole magnet.

性子ビームから平行度の高いビームのみを切り出 して試料に照射する。一方, 集光型小角散乱装置 では，試料の直上流に中性子集光素子を設置し， 検出器位置で中性子を集光する配置を採る（Fig. 6(b)）.よって, 通常の小角散乱装置と比較して, 発散度の大きい中性子ビームを用いることが出来 るため, 中性子の利用効率が高い[6,7].

Table 1 The specifications of the developed magnetic neutron lenses.

\begin{tabular}{|c|c|c|c|}
\hline & $\begin{array}{l}\text { Superconducting } \\
\text { Sextupole Magnet } \\
\end{array}$ & $\begin{array}{l}\text { Extended-Halbach } \\
\text { Sextupole Magnet }\end{array}$ & $\begin{array}{l}\text { Sextupole Pulse } \\
\text { Electro-Magnet }\end{array}$ \\
\hline $\begin{array}{c}\text { Manufacture } \\
\text { year }\end{array}$ & 2002 & 2002 & 2003 \\
\hline mode & Steady & Steady & Pulse \\
\hline $\begin{array}{l}\text { Magnetic field } \\
\text { gradient } G\end{array}$ & $\begin{array}{c}12,800 \mathrm{Tm}^{-2} @ 1.8 \mathrm{~K} \\
\left(9,480 \mathrm{Tm}^{-2} @ 4.2 \mathrm{~K}\right) \\
\end{array}$ & $23,000 \mathrm{Tm}^{-2}$ & $\sim 7,500 \mathrm{Tm}^{-2}$ (peak value) \\
\hline $\begin{array}{l}\text { Effective aperture } \\
\text { (diameter) }\end{array}$ & $\phi 46.8 \mathrm{~mm}$ & $\phi 25 \mathrm{~mm}$ & $\phi 22 \mathrm{~mm}$ \\
\hline $\begin{array}{c}\text { Focal length } f \\
\text { for } \lambda=6 \AA, L \text { mag }=2 m\end{array}$ & $\begin{array}{c}6.6 \mathrm{~m} @ 1.8 \mathrm{~K} \\
(8.6 \mathrm{~m} @ 4.2 \mathrm{~K})\end{array}$ & $3.9 \mathrm{~m}$ & $\sim 10.7 \mathrm{~m}$ \\
\hline
\end{tabular}


磁気レンズを集光型小角散乱装置の中性子集光 素子として用いる場合，一つの問題がある。それ は，負極性の中性子が磁気レンズに入射すると， それは磁気レンズにより発散され検出器面上に広 がり，バックグランドレベルを上げてしまうこと である。よって，磁気レンズに入射する負極性の 中性子成分を除去する必要がある。我々は, 中性 子偏極素子とスピン反転器を用いて負極性中性子 成分を除去するためのセットアップを構築した [8,9]. Fig. 7 に我々が JRR-3 の C3-1-2-1 ビームラ インに構築した実験セットアップを示す.我々は, 中性子偏極素子として冷中性子に対して高い偏極 度が得られる多層膜磁気ミラーを用いた。多層膜 磁気ミラーに中性子が入射すると, 正極性成分は 反射され, 負極性成分は透過する. 我々はその透 過中性子ビームを用いた。透過中性子ビームの偏 極度はP -0.97 であった。多層膜磁気ミラーを透 過した中性子の偏極度を保つために, 中性子ビー ム軸と平行方向にガイド磁場を発生するソレノイ ドコイルを設置し, その中に中性子ビームを通し て磁気レンズまで導いた。そして, 磁気レンズの 直上流に設置したスピン反転器を用いて, 中性子 を正極性の状態に反転してから，磁気レンズに入 射させた. スピン反転器としては, 白色中性子に 対して有効で, 且つ, 中性子ビーム軸上に物質を 置く必要のない高周波型のスピン反転器（RF gradiation spin flipper) を用いた. 本スピン反転器 は, $\lambda>4 \AA$ で $\phi 50 \mathrm{~mm}$ の中性子ビームに対してスピ ン反転効率 $f>0.99$ で動作するよう設計されている [10]. また, 磁気レンズ内の磁場は, 中性子ビー ム軸に対して垂直な面内の様々な方向に分布して いるので (式(4)), ガイド磁場と磁気レンズ内の 磁場が断熱的に接続するように, 磁気レンズの両 端部にソレノイドコイルを用いて二極磁場を印加 した.このセットアップを用いて測定した検出器 位置での中性子強度分布の動径平均值を Fig. 8 に 示す. 非偏極中性子ビームが入射した場合, 磁気 レンズの中性子集光効果により，r=0 を中心にピ 一クが現れるとともに $r=30 \mathrm{~mm}$ 付近に肩が現れた. この肩は, 磁気レンズにより発散された負極性成 分によるものと考えられた，そこで，偏極中性子 を入射させ， スピンフリッパーを On にして，正 極性成分を磁気レンズに入射させると，r=30 mm
付近の肩は消えた。ここで, スピンフリッパーを Off にして，負極性成分を磁気レンズに入射させ ると，再び肩が現れた，スピンフリッパーが Off の時に，r=0 を中心にピークが現れるのは，入射 中性子の偏極が完全ではなく, 僅かに混入してい る正極性の中性子が磁気レンズにより集光されピ 一クを形成したためと考えられる。また, 正極性 成分を磁気レンズに入射させた場合, 得られるピ 一ク強度とバックグランドレベルの比は $2 \times 10^{4}$ 程 度あり, 集光型小角散乱実験を行う上で十分高い S/N を与えることが示された。

次に，このセットアップを用いて中性子小角散 乱実験を行い, 小角散乱装置としての性能を評価 した. 試料には, 単分散シリカ粒子 (平均粒径 500 $\mathrm{nm}$ ）死用いた。波長は， $\lambda=9.15 \pm 0.30 \AA$ である. 得られた小角散乱強度を Fig. 9 に示寸. 実験結果 を解析した結果，本装置の角度分解能は， $\Delta q \sim 2.3$ $\times 10^{-4} \AA^{-1}$ であることが分かった。これは，同程度 のカメラ長を持った通常の小角散乱装置と比較し て約一桁小さい值である[9].

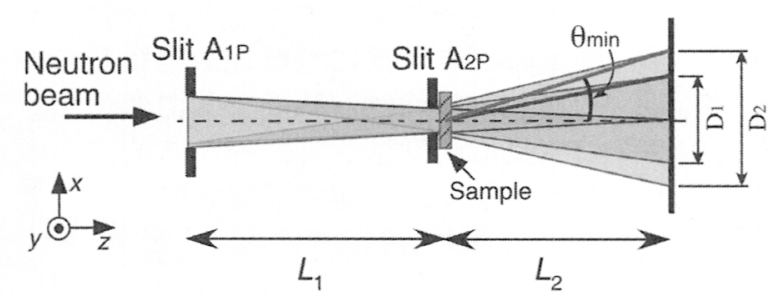

(a) Pinhole geometry

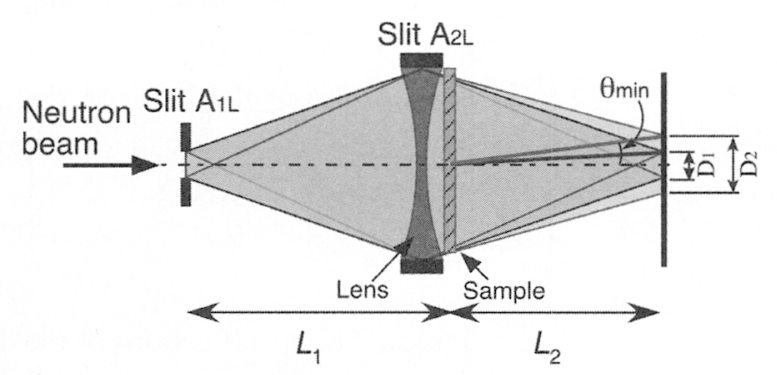

(b) Focusing geometry

Fig. 6 Beam collimation geometry for SANS. (a) Pinhole collimation geometry, (b) Focusing lens geometry.

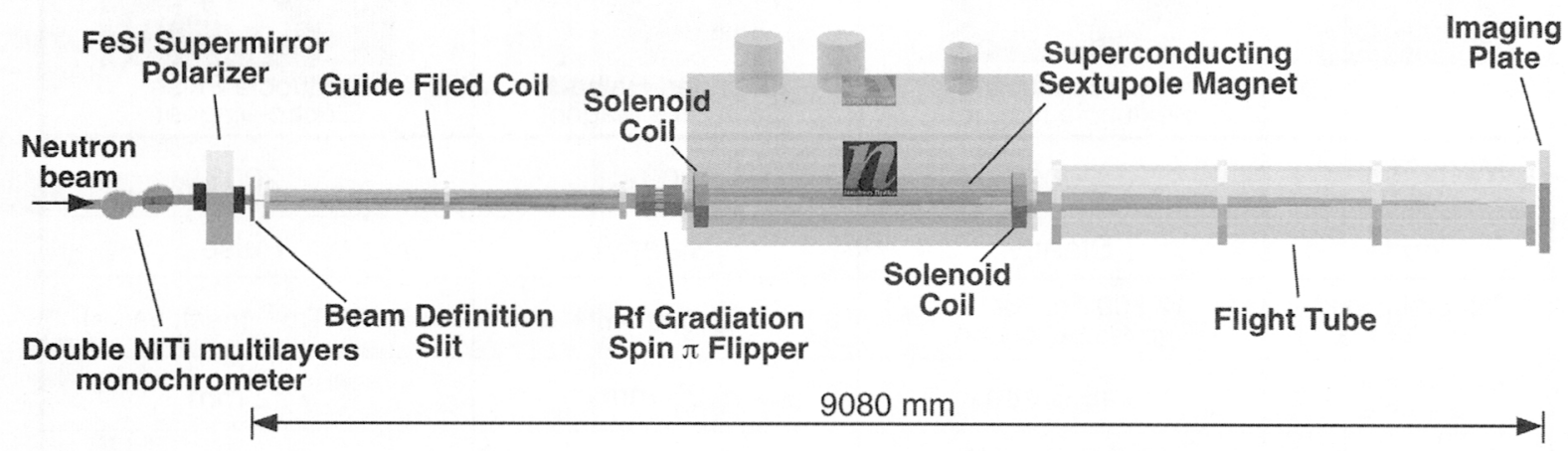

Fig. 7 Experimental setup of the Focusing geometry SANS using the superconducting magnetic lens. 


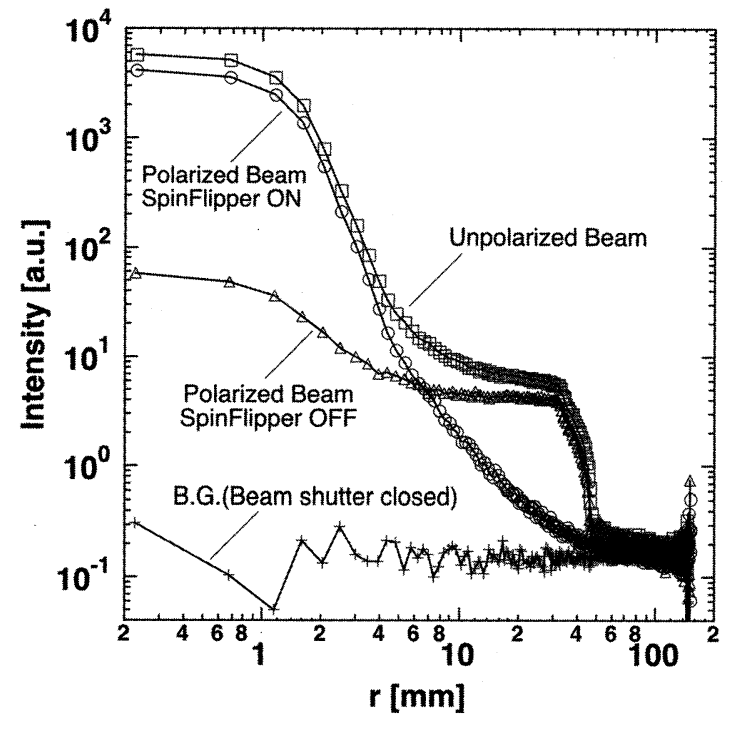

Fig. 8 Averaged intensities as a function of $r$, the distance from the peak position on the detector.

\section{5. 他の集光型小角散乱装置との比較}

小角散乱装置は利用する光学系により非集光型 と集光型に分類することができる（非収束型や収 束型と表現されることもある). 非集光型の装置に は，複数のピンホールの組み合わせにより得られ る平行性の高いビームを利用するピンホール型や

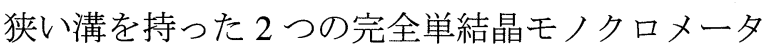
一により得られる単色性及び平行性の高いビーム を利用する Bonse-Hart 型[11]がある。これまでに 利用されてきた装置の多くはこの非集光型に属す るが，近年，非集光型の欠点を補うものとして， 集光素子を利用して角度分散の大きなビームを検 出器面に集光することで強度の増大と分解能の向 上を同時に得ることができる集光型の装置の開発 や応用に関する研究が進められている. 本節では, それらの中から磁気レンズ型, 複合両凹面レンズ 型，湾曲ミラー型，多チャンネル収束スリット型 の装置を取り上げ，それぞれの特徴を比較及び整 理する．ただし，各集光型において，入射ビーム の波長を共通（ $\lambda=6.5 \AA ）$ とするとともに，入射 ビームのアクセプタンス (実効開口角), 試料サイ ズ, 試料-検出器距離が同程度, すなわち, 具体的 には, $2 \mathrm{mrad}, \phi 20 \mathrm{~mm}, 10 \mathrm{~m}$ 程度になるような公 平な前提条件を設けた。

\section{1 磁気レンズ型}

Fig. 3 のように対象な光学系を考える. $\lambda=0.65 \mathrm{~nm}$ の中性子について $f=10 \mathrm{~m}$ とするには磁気レンズ 長 $L_{\mathrm{mag}}=657 \mathrm{~mm}$ と仮定した場合（後述の複合両凹 面レンズの全長と一致させてある.)， $G=19,940$ $\mathrm{Tm}^{-2}$ の磁気レンズを必要とするが，これは，ボー ア径を約 $\phi 25 \mathrm{~mm}$ とした発展型 Halbach 永久六極 磁石により実現される。 今の場合, 磁気レンズの 直後に $\phi 20 \mathrm{~mm}$ の試料を置くことで, 試料-検出器

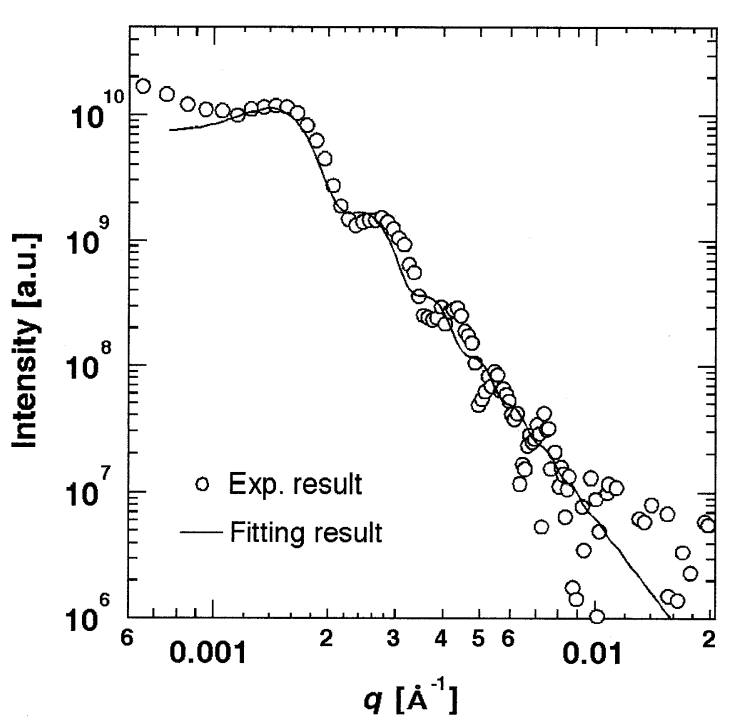

Fig. 9 Measured SANS intensity as a function of $q$.

距離を 9,672 mm（=約 $10 \mathrm{~m} ）$ として, 約 $2 \mathrm{mrad}$ のアクセプタンスのビームが利用されることにな る. ところで, 先述の通り, 磁気レンズは色収差

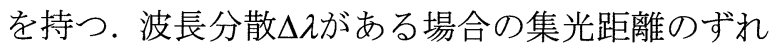
は $\Delta f I f \leq 2 \Delta \lambda / \lambda$ と与えられるが（ $\lambda \rightarrow 0$ の場合， $\Delta f l f=2 \Delta \lambda / \lambda$ であり, $(\Delta f f f) /(\Delta \lambda / \lambda)$ は $\lambda$ の増大に伴い 2 から減少する.), 今の場合, $\Delta f \mid f=1.96 \Delta \lambda / \lambda$ となる. また，前節で述べたように磁気レンズを小角散乱 法に応用する場合, 磁気レンズに入射するビーム を予め偏極素子により偏極させておくことが寄生 散乱の低減化の点から重要になる. 磁気レンズで は，ビーム経路に散乱体や吸収体がないので，偏 極素子により得られた偏極ビームは散乱や吸収さ れることなく試料に導かれる。したがって, 非偏 極ビームに対する偏極素子と磁気レンズの複合光 学系の透過率は, 基本的に偏極素子の透過率にの み規定され, 0.5 以下となる. この特徵は, 非偏極 ビーム実験の場合, 入射ビーム強度を半分以下に 減衰させるという点で欠点になるが, 偏極ビーム 実験の場合, 集光に伴う強度の減衰がないという 点で利点になる.

\section{2 複合両凹面レンズ型}

中性子複合両凹面レンズの開発は，X 線複合両 凹面レンズの開発に導かれたものである.X 線の 物質に対する屈折率は 1 より小さいが，ESRF の Snigirev らは, $\mathrm{Al}-\mathrm{Cu}$ 合金に直径 $0.6 \mathrm{~mm}$ の円柱状 の穴を 30 個直線配列することで, $14 \mathrm{keV}$ の X 線 に対して焦点距離 $1.8 \mathrm{~m}$ の複合両凹面レンズを開 発した[12]. Risøの Eskildsen らは, 同様のアイデ アに基づき, 中性子に対する屈折率が高く, 吸収 が少なく, 散漫散乱の少ない素材として, 赤外線 のレンズに利用されている $\mathrm{MgF}_{2}$ 単結晶に注目し て複合両凹面レンズを開発した[13]. その後, こ のレンズは, NIST の小角散乱装置[6]をはじめと して, JRR-3 の小角散乱装置[14]などにも搭載, 利 
用されている.

さて, 複合両凹面レンズの集光距離 $f$ は, 㛜密 に式で記述することは出来ないが， $f$ に比べて複 合レンズ長さが十分短い場合, 次式で記述できる.

$$
f \sim \frac{R}{\delta N}
$$

ただし, $R$ は四面の曲率半径, $\delta$ は屈折率 $n$ と $\delta=1-n$ の関係にあり, $\mathrm{MgF}_{2}$ 単結晶の場合, $\delta=8.14 \times 10^{-7}(\lambda$ $[\AA])^{2}, N$ は両凹面レンズの枚数である. $\lambda=6.5 \AA$ の中性子について $f=10 \mathrm{~m}$ とするには, $R=25 \mathrm{~mm}$, 中心厚 $=1 \mathrm{~mm}$, こば厚 $=9 \mathrm{~mm}$ の両凹面レンズを $N=73$ 枚重齐孔ば良い。この場合, 複合両凹面レン ズの全長は $657 \mathrm{~mm}$, 有効径は約 $\phi 25 \mathrm{~mm}$ になる. また, 磁気レンズ型の場合と同様に対称な光学系 を考え (Fig. 10(a)), 複合両凹面レンズの直後に $\phi 20$ $\mathrm{mm}$ の試料を置くことで, 試料-検出器距離を 9,672 $\mathrm{mm}$ (=約 $10 \mathrm{~m})$ として, 約 $2 \mathrm{mrad}$ のアクセプタ ンスのビームが利用されることになる. 複合両凹 面レンズの集光距離 $f$ は $\delta$ をして波長に依存す る. 寸なわち, 磁気レンズの場合と同様に, 複合

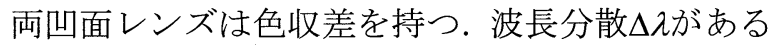
場合の集光距離のずれは, 式(14)によると $\Delta f l f=2 \Delta \lambda / \lambda$ となることが分かるが，式(14)が近似式 であることを考えると磁気レンズの集光距離のず れとほぼ同程度であるといえる，ところで，複合 両凹面レンズの $\phi 20 \mathrm{~mm}$ のビーム径当りの平均の 厚みは $223.3 \mathrm{~mm}$ と計算されるが, $\lambda=6.5 \AA$ の中性 子に関する $\mathrm{MgF}_{2}$ 単結晶の吸収断面積 $\Sigma_{\mathrm{a}}$ は $9.04 \times$ $10^{-3} \mathrm{~cm}^{-1}$ であるので，これらの值から期待される $\phi 20 \mathrm{~mm}$ のビーム径当りの透過率は約 0.82 となる. しかし, 実験的に得られる透過率は 0.432 (室温) とこの值より小さい. 最近, 複合両凹面レンズの 透過率の泠却による増大が確認されていることか ら, このずれは, $\mathrm{MgF}_{2}$ 単結晶内部の欠陥や熱摇ら ぎによるビームの散乱に起因すると考えられてい る[15]. これらのビームの散乱は, 透過率の減衰 だけでなく寄生散乱の増大にもつながる.また， 複合両凹面レンズは, 界面屈折光学素子であるの で, 加工による界面の乱れも寄生散乱を増大させ ることになる.

\section{3 湾曲ミラー型}

Fig. 10(b)のように回転楕円体ミラーを利用した 対称な集光光学系を考える. 焦点 $F_{1}$ からの発散ビ 一ムは, 回転棈円体ミラーにより反射され, 別の 焦点 $F_{2}$ に集光される. 回転楕円体ミラーの中心 $P$ から焦点 $F_{2}$ までの距離を集光距離 $f$ と定義して $f=10 \mathrm{~m}$ となるようにする. まず，ミラー面として は FZJ の小角散乱装置 KWS-3 に採用されている 湾曲ミラー[6]と同様の ${ }^{65} \mathrm{Cu}$ コート面を考える.こ の場合, $\lambda=6.5 \AA$ の中性子についての臨界角度は $11.2 \mathrm{mrad}$ となるので, $\phi 20 \mathrm{~mm}$ の試料に対して, 約 $2 \mathrm{mrad}$ のアクセプタンスのビームを利用する ためには, 回転楕円体ミラーの全長を約 $1,786 \mathrm{~mm}$, 回転楕円体ミラー-焦点垂直距離を $112 \mathrm{~mm}$ 以下に
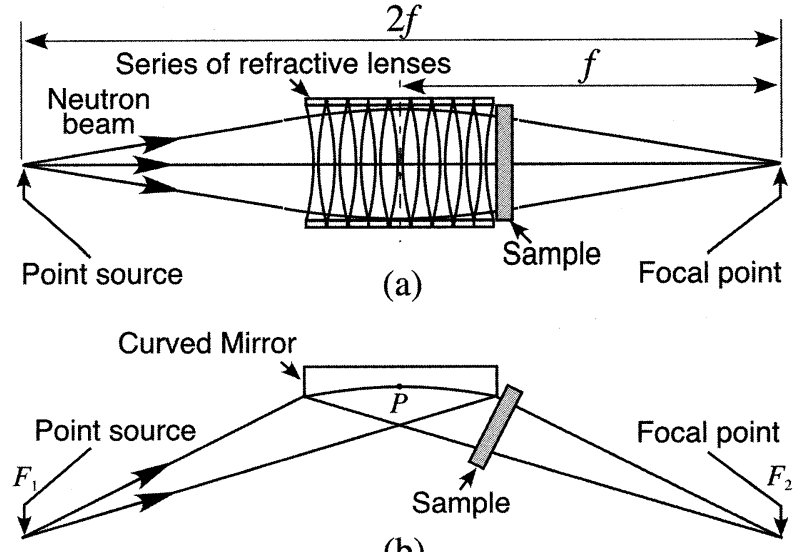

(b)

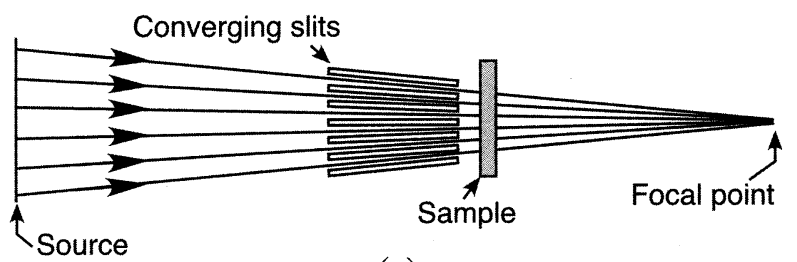

(c)

Fig. 10 Setups of the F-SANS experiments using (a) refractive lenses, (b) a curved mirror and (c) converging slits.

すれば良い。このとき, 回転棈円体ミラーの曲率 半径は約 $891 \mathrm{~m}$ である。 もし, 臨界角度が $2 \phi_{\mathrm{c}}^{\mathrm{Ni}}$ の 回転棈円体スーパーミラーが実現されれば, $\lambda=6.5$ 凡の中性子についての臨界角度は $22.1 \mathrm{mrad}$ とな るので，回転棈円体ミラーの全長を約 $905 \mathrm{~mm}$, 回転棈円体ミラー-焦点垂直距離を $221 \mathrm{~mm}$ 以下に すれば良い. このとき, 回転楕円体ミラーの曲率 半径は約 $452 \mathrm{~m}$ である. 湾曲ミラー型では, 全反 射により集光を行うので実効的な透過率は 1 にな る. また, 湾曲ミラー型では, 色収差がないのは 利点であるが，ミラー面に乱れや歪みがあると焦 点がぼけるとともに寄生散乱が増大することにな る.

\section{4 多チャンネル収束スリット型}

Fig. 10(c)のように多チャンネル収束スリットを 利用した集光光学系を考える. 第 1 スリットから の発散ビームは, 多チャンネル収束スリットによ り検出器面に集光される. この場合, $\phi 20 \mathrm{~mm} の$ 試料を試料-検出器距離が $9,672 \mathrm{~mm}$ になる位置に 置くことにより, 約 $2 \mathrm{mrad}$ のアクセプタンスのビ 一ムが利用されることになる. 多チャンネル収束 スリット型では，スリットの存在により実効的な 透過率は 1 以下になる。 また, 多チャンネル収束 スリット型でも, 色収差がないのは利点であるが, スリット面による反射や散乱が寄生散乱を増大さ せることになる. 集光光学素子としてキャピラリ ーファイバーから構成される Kumakhov レンズを 利用した集光光学系も多チャンネル収束スリット 型と同様の機能を有する. Kumakhov レンズを利 用する小角散乱装置の可能性は NIST の Mildner 
により検討されているが[16], Kumakhov レンズで の多重反射に伴うビームの減衰や有効ビーム断面 積に関する制限が小角散乱法への応用を困難にし ているようである。

以上, 4 つの型の小角散乱装置の特徴について 述べたが，いずれの型の装置でも同程度のアクセ プタンスのビームを利用することができる．すな わち，利用できるビームの強度は，透過率の違い の範囲内で同程度である(極端な差は生じない.) . したがって, 集光素子を選択する場合には, 各集 光素子の他の特徵をどう活かすかもポイントにな る. 例えば, 磁気レンズは, 高分解能実験や偏極 ビーム実験に有効である. しかし, 高分解能を要 求しないのであれば，複合両凹面レンズを利用す ることができる．また，色収差が問題であれば, 湾曲ミラーや多チャンネル収束スリットを選択す ることもできる，本節では，ビームのアクセプタ ンスを $2 \mathrm{mrad}$ 程度としたが, より大きなアクセプ タンスのビームを利用するためには, 磁気レンズ や複合両凹面レンズの場合, 口径を大きくする必 要がある. 口径を大きくすることにより, 磁気レ ンズの透過率は影響を受けないが，複合両凹面レ ンズの透過率は実効的なレンズの厚みの増大によ り減少する。この問題を克服するために Fresnel 形状のレンズを利用した複合レンズの開発が進め られている[17]. 価格に関しては, 現在のところ, 磁気レンズは湾曲ミラーと同程度であるが，複合 両凹面レンズや多チャンネル収束スリットに比べ れば高価である。したがって, 磁気レンズや湾曲 ミラーを選択する場合, 期待する性能が投資に見 合ったものであることを検討することも必要であ る. 実際, JRR-3 の小角散乱装置 SANS-J では, 実験目的に合わせて, 磁気レンズ及び複合両凹面 レンズを使い分ける計画である[14].

おわりに

我々は，六極磁石を利用した中性子磁気レンズ を世界に先駆けて開発し, 実用化することに成功 した. 本稿では, 中性子磁気レンズの集光型中性 子小角散乱法への応用について紹介したが, 中性 子磁気レンズは他の中性子散乱法や高効率の中性 子導管にも適用できるポテンシャルを有すると考 えている. 本稿で紹介した成果は, 科学技術振興 調整費課題「中性子光学素子の開発と応用 (NOP)」 及び日本原子力研究所先端基礎研究センターの研 究課題の下での多くの方々との議論や共同研究に 基づいたものである. 全国組織である NOP グルー プのメンバー, 日本原子力研究所先端基礎研究セ ンター中性子光学研究グループ, ソフトマター中 性子散乱研究グループのメンバーに感謝する.
参考文献

[1] H. M. Shimizu, Y. Suda, T. Oku, H. Nakagawa, H. Kato, T. Kamiyama, C. Otani, H. Sato, T. Wakabayashi and Y. Kiyanagi, Nucl. Instr. and Meth. A 430 (1999) 423.

[2] T. Oku, J. Suzuki, T. Adachi, K. Sakai, K. Ikeda, T. Morishima, Y. Kiyanagi, M. Furusaka, T. Tsuzaki and H. M. Shimizu, Proc. of the ICANS-XVI, Düsseldorf, May, 2003, p.355.

[3] J. Suzuki, T. Oku, T. Adachi, H. M. Shimizu, T. Hirumachi, T. Tsuchihashi and I. Watanabe, J. Appl. Cryst. 36 (2003) 795.

[4] J. Suzuki, T. Oku, T. Adachi, H. M. Shimizu, Y. Kiyanagi and M. Furusaka, Proc. of the ICANS-XVI, Düsseldorf, May, 2003, p.427.

[5] J. Suzuki, T. Oku, T. Adachi, H. M. Shimizu, Y. Kiyanagi, T. Kamiyama, F. Hiraga, H. Iwasa, K. Sato and M. Furusaka, Nucl. Instr. and Meth. A 529 (2004) 120.

[6] B. Alefeld, C. Hayes, F. Mezei, D. Richter and T. Springer, Physica B 234-236 (1997) 1052.

[7] S.-M. Choi, J. G. Barker, C. J. Glinka, Y. T. Cheng and P. L. Gammel, J. Appl. Cryst. 33 (2000) 793.

[8] T. Oku, J. Suzuki, H. Sasao, T. Adachi, T. Shinohara, K. Ikeda, T. Morishima, K. Sakai, Y. Kiyanagi, M. Furusaka and H. M. Shimizu, Nucl. Instr. and Meth. A 529 (2004) 116.

[9] T. Oku, J. Suzuki, H. Sasao, S. Yamada, M. Furusaka, T Adachi, T. Shinohara, K. Ikeda, and H. M. Shimizu, Physica B (2004), in press.

[10] T. Oku, K. Sakai, T. Adachi, K. Ikeda, H. M. Shimizu, R. Maruyama, M. Hino, S. Tasaki, Y. Kiyanagi, T. Kamiyama, H. Iwasa, K. Sasaki, T. Ino, M. Furusaka, D. Yamazaki, J. Suzuki and T. Ebisawa, Physica B 335 (2003) 226.

[11] U. Bonse and M. Hart, Appl. Phys. Lett. 7 (1965) 238.

[12] A. Snigirev, V. Kohn, I. Snigireva and B. Lengeler, Nature 384 (1996) 49.

[13] M. R. Eskildsen, P. L. Gammel, E. D. Isaacs, C. Detlefs, K. Mortensen and D. J. Bishop, Nature 391 (1998) 563.

[14] 小泉智, 岩瀬裕希, 田中宏和, 橋本竹治, 鈴 木淳市, 奥隆之, 笹尾一, 清水裕彦, 波紋 14 (2004) 266.

[15] 笹尾一, 岩瀬裕希, 池田圭太, 山田悟, 奥隆 之, 鈴木淳市, 小泉智, 田中宏和, 橋本竹治, 篠原 武尚, 安達智宏, 清水裕彦, 日本中性子科学会第 4 回年会, 札幌, Dec. 16-17, 2004.

[16] D. F. R. Mildner, J. Appl. Cryst. 27 (1994) 521.

[17] T. Adachi, K. Ikeda, T. Shinohara, K. Hirota, T. Oku, J. Suzuki, H. Sato, K. Hoshino, J. Guo, W. Lin, H. Ohmori, H. M. Shimizu, K. Sakai, K. C. Littrell and C.-K. Loong, Nucl. Instr. and Meth. A 529 (2004) 112. 